\title{
Phage Mu-driven two-plasmid system for integration of recombinant DNA in the Methylophilus methylotrophus genome
}

\author{
Elena G. Abalakina • Irina L. Tokmakova • \\ Natalya V. Gorshkova • Evgueni R. Gak • \\ Valerii Z. Akhverdyan • Sergey V. Mashko • \\ Yurgis A. V. Yomantas
}

Received: 10 July 2008 /Revised: 27 August 2008 /Accepted: 1 September 2008 / Published online: 27 September 2008

(C) The Author(s) 2008. This article is published with open access at Springerlink.com

\begin{abstract}
A phage Mu-driven two-plasmid system for DNA integration in Escherichia coli genome has been adjusted for Methylophilus methylotrophus. Constructed helper plasmids with broad-host-range replicons carry thermo-inducible genes for transposition factors $\mathrm{MuA}$ and MuB. Integrative plasmids that are only replicated in E. coli could be mobilized to M. methylotrophus and contained mini-Mu unit with a short terminus of Mu DNA, Mu-attL/ $R$. Mini-Mu unit was integrated in the M. methylotrophus genome via mobilization of the integrative plasmid to the cells carrying the helper in conditions of thermo-induced expression of $\mathrm{Mu} A$ and $\mathrm{Mu} B$. In this system, mini-Mu unit was mainly integrated due to replicative transposition, and the integrated copy could be amplified in the M. methylotrophus chromosome in the presence of helper plasmid. A kan-gene flanked by FRT sites was inserted in one of the mini-Mu units, and it could be readily excised by yeast FLP recombinase that is encoded by the designed plasmid. The multiple Mu-driven gene insertion was carried out by integration of the Bacillus amyloliquefaciens $\alpha$-amylase gene followed by curing the $\mathrm{Km}^{\mathrm{R}}$ marker before integration of the second mini-Mu unit with Pseudomonas putida xylE gene encoding catechol 2,3-dioxygenase (C23O).
\end{abstract}

E. G. Abalakina I. L. Tokmakova $(\triangle) \cdot$ N. V. Gorshkova E. R. Gak $\cdot$ V. Z. Akhverdyan · S. V. Mashko $\cdot$ Y. A. V. Yomantas Ajinomoto-Genetika Research Institute,

117545 Moscow, Russian Federation

e-mail: irina_tokmakova@agri.ru
Keywords Methylotrophs · Mini-Mu unit .

Replicative transposition · Amplification · Excisable marker

\section{Introduction}

Methylotrophs are a diverse group of organisms that are capable of growing on single-carbon substrates, such as methane or methanol, as sole sources of organic carbon and energy. The availability of the raw material and its relatively low price make methylotrophic bacteria interesting candidates as producers of numerous biologically active compounds. Therefore, these microorganisms are currently becoming more and more widely used in the manufacturing of natural and recombinant proteins (Bélanger et al. 2004; Fitzgerald and Lidstrom 2003), polysaccharides, amino acids, and vitamins (Bourque et al. 1995; Korotkova et al. 2002; Motoyama et al. 1993, 2001).

The industrial application of methylotrophs has focused attention on the investigation of genetic regulation of C-1 metabolism (Anthony 1993). However, the majority of these bacteria have been poorly studied, and the genetic tools required for their investigation are limited. The Methylophilus methylotrophus that is the subject of our investigation is especially hard to manipulate genetically because the majority of amino acids fail to penetrate in and export out of its cells, and therefore, the conventional methods for obtaining auxotrophic mutants are inapplicable under the circumstances. On the other hand, existing data on efficient expression of a few Escherichia coli genes in 
M. methylotrophus (see for example Gunji and Yasueda 2006; Tsujimoto et al. 2006) permit the hope of practical application of well-developed genetic systems to these methylotrophs.

Along with design of plasmid vectors, improvement of transposon mutagenesis is one of the priority genetic techniques for cloning and gene expression in methylotrophic bacteria (Koch et al. 2001; Marx and Lidstrom 2001, 2004). For example, a possibility of using $\operatorname{Tn} 7$ for sitespecific integration of recombinant DNA in the genome of Methylobacterium extorquens was demonstrated (Choi et al. 2006). The system can be applied to integration in a unique site in the recipient bacterial genome (Koch et al. 2001). In order to allow multiple integration of several copies of gene of interest and/or many dissimilar genes in different points of bacterial genome, the use of a wellinvestigated, both in vivo and in vitro, mobile genetic element, bacteriophage-transposon Mu (Mizuuchi 1983), seemed most promising.

It is known that $\mathrm{Mu}$ employs two transposition mechanisms depending on the stage of the vital cycle: (1) simple insertion upon infection and introduction of its linear DNA, practically, into the random point of the bacterial genome and (2) replicative transposition via formation of cointegrates at the lytic development and amplification of phage DNA (Craigie and Mizuuchi 1985; Sokolsky and Baker 2003).

Although some undetermined details that are being intensely investigated (see for example Yin et al. 2007) remain in the mechanism of $\mathrm{Mu}$ transposition, efficient systems for integration of recombinant DNA in vitro (Haapa et al. 1999) and in vivo in E. coli (Akhverdyan et al. 2007; Groisman and Casadaban 1987) and Salmonella typhimurium (Lawes and Maloy 1995) chromosomes have already been designed on its basis and are rather actively being used. In the present study, we have shown that it is also possible to perform the Mu-driven integration of recombinant DNA in the chromosome of M. methylotrophus. To this end, first of all, helper plasmids with thermoinducible genes encoding transposition factors of phage $\mathrm{Mu}(\mathrm{Mu} A$ and $\mathrm{Mu} B)$ were constructed on the basis of broad-host-range replicons of IncP and IncQ incompatibility groups. Integrative vectors, plasmids with constructed mini-Mu units that are capable of mobilization transfer to M. methylotrophus cells, were also designed. Mini-Mu units from the integrative vectors flanked by $\mathrm{Mu}$-attL and Mu-attR DNA fragments were transposed in the chromosome of M. methylotrophus during the induced synthesis of $\mathrm{MuA}$ and MuB. Mini-Mu unit contained kanamycin resistance gene (kan) flanked with $F R T$ sites that permitted the selection of integrants for their resistance to kanamycin $(\mathrm{Km})$ and then to eliminate the marker from the bacterial chromosome exploiting the Saccharomyces cerevisiae
FLP-FRT-mediated site-specific recombination system (Senecoff et al. 1985) adjusted to expression in $M$. methylotrophus.

\section{Materials and methods}

Bacterial strains, plasmids, and cultivation conditions

Strains and plasmids used in the study are shown in Table 1. Cells of M. methylotrophus AS1 were grown at $37^{\circ} \mathrm{C}$ on a mineral medium SEIIa (Gunji et al. 2004) of the following composition: $\mathrm{K}_{2} \mathrm{HPO}_{4}, 1.9 \mathrm{~g}$; $\mathrm{NaH}_{2} \mathrm{PO}_{4} \times 2 \mathrm{H}_{2} \mathrm{O}, 1.56 \mathrm{~g}$; $\left(\mathrm{NH}_{4}\right)_{2} \mathrm{SO}_{4}, 5 \mathrm{~g} ; \mathrm{MgSO}_{4} \times 7 \mathrm{H}_{2} \mathrm{O}, 200 \mathrm{mg} ; \mathrm{CaCl}_{2} \times 2 \mathrm{H}_{2} \mathrm{O}$, $72 \mathrm{mg} ; \mathrm{CuSO}_{4} \times 5 \mathrm{H}_{2} \mathrm{O}, 5 \mu \mathrm{g} ; \mathrm{MnSO}_{4} \times 5 \mathrm{H}_{2} \mathrm{O}, 25 \mu \mathrm{g}$; $\mathrm{ZnSO}_{4} \times 7 \mathrm{H}_{2} \mathrm{O}, 23 \mu \mathrm{g} ; \mathrm{FeCl}_{3} \times 6 \mathrm{H}_{2} \mathrm{O}, 9.7 \mathrm{mg} / \mathrm{l}$, methanol $2 \%, \mathrm{pH} 7.0$. Bactoagar (1.2\%, Difco, USA) and methanol $1 \%$ were applied to the solid media. M. methylotrophus AS1 was resistant to chloramphenicol $(\mathrm{Cm})$, thus permitting the employment of this antibiotic to the counterselection of donor E. coli S17-1-based strains in bacterial mating experiments (see below). Antibiotics to maintain plasmid DNA in M. methylotrophus were added at the following concentrations: ampicillin (Ap), $100 \mu \mathrm{g} / \mathrm{ml}$; tetracycline (Tc), $2 \mu \mathrm{g} / \mathrm{ml}$; and streptomycin (Sm), $50 \mu \mathrm{g} / \mathrm{ml}$. Km $(10 \mu \mathrm{g} / \mathrm{ml})$ and $\mathrm{Cm}(20 \mu \mathrm{g} / \mathrm{ml})$ were used for selection of the integrants and counter-selection of the donor, respectively. Selection of clones containing the amplified mini-Mu \{[FRT$\mathrm{Km}^{\mathrm{R}}$-FRT]-Sm$\left.{ }^{\mathrm{R}}\right\}$ unit in the M. methylotrophus chromosome was performed on agar medium SEIIa with the Sm content of $2 \mathrm{mg} / \mathrm{ml}$. The E. coli strains were cultured at $37^{\circ} \mathrm{C}$ on liquid or solid Luria-Berthani (LB) medium; $1.2 \%$ of bactoagar was added in the latter case (Sambrook and Russell 2001). The antibiotics (Ap, $200 \mu \mathrm{g} / \mathrm{ml}$; Tc, $20 \mu \mathrm{g} / \mathrm{ml}$; and Sm, $50 \mu \mathrm{g} / \mathrm{ml}$ ) were added during growth of the appropriate E. coli plasmid strains. All manipulations with strains $M$. methylotrophus AS1 and $E$. coli with plasmids containing thermo-inducible genes, $\mathrm{Mu} A, \mathrm{Mu} B$, or $F L P$, were carried out at $30^{\circ} \mathrm{C}$ unless induction was not required. Selection of the in vitro constructed recombinant plasmids was conducted in the strains E. coli TG1 and E. coli $\mathrm{S} 17-1$.

Standard gene engineering methods

The treatment of recombinant DNA and the Southern hybridization was carried out in accordance to conventional protocols (Sambrook and Russell 2001). Preparations of restrictases, T4 DNA ligases, and DNA polymerase I Klenow fragment from Fermentas (Lithuania) were used. Taq DNA polymerase (Fermentas) or AccuTaqLA DNA polymerase (Sigma) were used in accordance with the manufacturer's instructions to provide polymerase chain 
Table 1 Strains and plasmids used in this study

\begin{tabular}{|c|c|c|}
\hline Strain and plasmid & Relevant characteristics & Reference or source \\
\hline \multicolumn{3}{|l|}{ Strains } \\
\hline M. methylotrophus AS-1 & Wild type & NCIMB10515 \\
\hline \multicolumn{3}{|l|}{ E. coli } \\
\hline TG1 & $\left(\mathrm{F}^{-}\right) \Delta$ (lac-pro) supE thi hsd $\Delta 5 / \mathrm{F}^{\prime}$ traD36 $\operatorname{proA}^{+} \mathrm{B}^{+}$lacI $^{\mathrm{q}}$ lacZ $\Delta \mathrm{M} 15$ & VKM IMG-341 \\
\hline S17-1 & $\mathrm{Tp}^{\mathrm{R}} ; \mathrm{Sm}^{\mathrm{R}} ;\left(\mathrm{F}^{-}\right)$RecA pro thi hsdR ${ }^{-} \mathrm{hsdM}^{+} \mathrm{RP} 4-2-\mathrm{Tc}:: \mathrm{Mu}-\mathrm{Km}:: \mathrm{Tn} 7$ & ATCC47055 \\
\hline \multicolumn{3}{|c|}{ 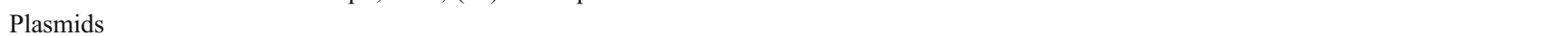 } \\
\hline pRK310 & $\mathrm{Tc}^{\mathrm{R}}$; IncP $\alpha \mathrm{Tra}^{-}$broad-host-range cloning vector derived from RP4 & Ditta et al. 1985 \\
\hline pAYC32 & $\begin{array}{l}\mathrm{Ap}^{\mathrm{R}} ; \mathrm{Sm}^{\mathrm{R}} ; \text { IncQ broad-host-range cloning vector derived from } \\
\text { RSF1010::Tn1 }\end{array}$ & Chistorerdov and Tsygankov 1986 \\
\hline pAYCTER3 & $\mathrm{Ap}^{\mathrm{R}}$; IncQ broad-host-range cloning vector derived from pAYC32 & Gulevich et al. 2006 \\
\hline pUC-MuAB & $\begin{array}{l}\mathrm{Ap}^{\mathrm{R}} \text {; pUC1918 with the } 5.7 \mathrm{~kb} S c a \mathrm{I}-E c o 47 \mathrm{III} \text { fragment from } \\
\text { pMud4041containing the } \mathrm{Mu} A B \text { ner } c^{\text {ts }} \text { genes }\end{array}$ & Akhverdyan et al. 2007 \\
\hline pSUP5011 & $\mathrm{Ap}^{\mathrm{R}} ; \mathrm{Cm}^{\mathrm{R}} ; \mathrm{Neo}^{\mathrm{R}} ; \mathrm{pBR} 325\left(\mathrm{Bam}^{-}\right):: \operatorname{Tn} 5-\mathrm{Mob}^{+}{ }_{\mathrm{RP}}$ & Simon et al. 1983, 1984 \\
\hline pKD4 & $\mathrm{Km}^{\mathrm{R}} ; \mathrm{Ap}^{\mathrm{R}} ; \mathrm{pANTS} \gamma\left[\mathrm{FRT}-\mathrm{Km}^{\mathrm{R}}-\mathrm{FRT}\right]$ & Datsenko and Wanner 2000 \\
\hline pCP20 & $\mathrm{Cm}^{\mathrm{R}} ; \mathrm{Ap}^{\mathrm{R}} ;$ plasmid with $\lambda c I_{857^{\text {ts }}} \lambda c r o-F L P$ & Datsenko and Wanner 2000 \\
\hline pUX1918 & $\mathrm{Ap}^{\mathrm{R}} ; \mathrm{pUC} 1918-X y l E$ & Schweizer 1993 \\
\hline pRT5 & $\begin{array}{l}\text { pSM19035 deletion derivative containing the } B \text {. amyloliquiefaciens } \\
\text { amyE gene }\end{array}$ & Smirnova et al. 1988 \\
\hline pHP17 & $\mathrm{Ap}^{\mathrm{R}} ; \mathrm{Sm}^{\mathrm{R}} \mathrm{pAYCTER} 3$ with the $M$. methylotrophus promoter $\mathrm{P} 17$ & Tokmakova, unpublished \\
\hline pMIV5 & $\begin{array}{l}\mathrm{Ap}^{\mathrm{R}} \text {; pMW119 with mini-Mu containing } \mathrm{MCS}_{\mathrm{pUC59}} \text { flanked with } \\
\text { transcription terminators } t h r L \text { and } 2 \mathrm{fd} \text { between Mu-attL/R }\end{array}$ & Tokmakova et al. 2007 \\
\hline pMIV5-Mob & $\begin{array}{l}\text { Ap }{ }^{\mathrm{R}} \text {; pMIV5 derivative containing the Bam HI fragment from } \\
\text { pSUP5011, including } \mathrm{Mob}^{+}{ }_{\mathrm{RP} 4}\end{array}$ & This study \\
\hline $\begin{array}{l}\text { pMIV5-Mob-[FRT-Km }{ }^{\mathrm{R}}- \\
\text { FRT] }\end{array}$ & $\begin{array}{l}\mathrm{Ap}^{\mathrm{R}} ; \mathrm{Km}^{\mathrm{R}} ; \text { pMIV5-Mob with the } 1.5 \mathrm{~kb} \text { HindIII-NdeI fragment } \\
\text { from pKD4 containing the } \mathrm{Km}^{\mathrm{R}} \text { gene flanked } F R T \text { sites }\end{array}$ & This study \\
\hline $\begin{array}{l}\text { pMIV5-[FRT-Km }{ }^{\mathrm{R}} \text {-FRT]- } \\
\text { amy-Mob; }\end{array}$ & $\begin{array}{l}\mathrm{Ap}^{\mathrm{R}} ; \mathrm{Km}^{\mathrm{R}} ; \mathrm{pMIV5-Mob}\left[\mathrm{FRT}-\mathrm{Km}^{\mathrm{R}}-\mathrm{FRT}\right] \text { with the } 2.9 \mathrm{~kb} \text { BglII-Bam } \mathrm{HI} \\
\text { fragment from pRT5 containing the } \text { B. amyloliquiefaciens amyE gene }\end{array}$ & This study \\
\hline $\begin{array}{l}\text { pMIV5-[FRT-Km }{ }^{\mathrm{R}} \text {-FRT]- } \\
\text { xyl-Mob; }\end{array}$ & $\begin{array}{l}\text { Ap }^{\mathrm{R}} ; \mathrm{Km}^{\mathrm{R}} ; \text { pMIV5-Mob-[FRT-Km }{ }^{\mathrm{R}} \text {-FRT] with the EcoRI fragment } \\
\text { from pX1918 containing the } P \text {. putida xylE gene }\end{array}$ & This study \\
\hline $\begin{array}{l}\left.\text { pMIV5-[FRT-Km }{ }^{\mathrm{R}}-\mathrm{FRT}\right]- \\
\text { Sm }^{\mathrm{R}}-\mathrm{Mob}\end{array}$ & $\begin{array}{l}\left.\mathrm{Ap}^{\mathrm{R}} ; \mathrm{Km}^{\mathrm{R}} ; \mathrm{Sm}^{\mathrm{R}} ; \text { pMIV5-Mob[FRT-Km }{ }^{\mathrm{R}}-\mathrm{FRT}\right] \text { with the } 1.9 \mathrm{~kb} \text { Eco RV } \\
\text { fragment containing the strAB genes under control the M. methylotrophus } \\
\text { promoter P17 }\end{array}$ & This study \\
\hline pTP310 & $\begin{array}{l}\mathrm{Tc}^{\mathrm{R}} \text {; pRK310 with the } 5.7 \mathrm{~kb} \text { Bam } \mathrm{HI} \text { fragment from pUC-MuAB } \\
\text { containing the } \mathrm{Mu} A B \text { ner } c^{\text {ts }} \text { genes }\end{array}$ & This study \\
\hline pAET7 & $\begin{array}{l}\mathrm{Ap}^{\mathrm{R}} ; \mathrm{Sm}^{\mathrm{R}} ; \mathrm{pAYC} 32 \text { with the } 5.7 \mathrm{~kb} \text { Bam HI fragment from pUC-MuAB } \\
\text { containing the MuAB ner } c^{\mathrm{ts}} \text { genes }\end{array}$ & This study \\
\hline pFLP31 & $\begin{array}{l}\mathrm{Ap}^{\mathrm{R}} ; \mathrm{Sm}^{\mathrm{R}} ; \text { pAYCTER } 3 \text { with the } 3,3 \mathrm{~kb} \text { SmaI-BamHI fragment from } \\
\text { pCP20 containing the } \lambda c I_{857}{ }^{\text {ts }} \lambda \text { cro-FLP genes }\end{array}$ & This study \\
\hline
\end{tabular}

reaction (PCR) for confirmation the chromosomal modifications. The primers P1:5'-ttagatttggtggggcttgc $\rightarrow$ 3'; P2: $5^{\prime}$-gtttatcagcttgctttcgagg $\rightarrow 3^{\prime}$ were used. The Biotin DecaLabel $^{\mathrm{TM}}$ kit and biotin chromogenic detection kits (Fermentas) were used to label and detect DNA probes in Southern hybridization.

Construction of recombinant plasmids

pAET7 $\left(\mathrm{Ap}^{\mathrm{R}}, \mathrm{Sm}^{\mathrm{R}}\right)$ was obtained on the basis of pAYC32 (Chistorerdov and Tsygankov 1986) by cloning of BamHI fragment from pUC-MuAB (Akhverdyan et al. 2007).

pTP310 $\left(\mathrm{Tc}^{\mathrm{R}}\right)$ was a result of cloning the same BamHI fragment of pUC-MuAB in broad-host-range replicon
pRK310, a derivative of plasmid RP4/RK2 of IncP $\alpha$ group (Ditta et al. 1985; Pansegrau et al. 1994).

pMIV5 (Tokmakova et al. 2007) containing a multiplecloning site (MCS) flanked with transcription terminators between $\mathrm{Mu}-a t t L$ and $\mathrm{Mu}-a t t R$ was used as a vector for construction of the integrative plasmids. In order to obtain pMIV5-Mob, the blunted BamHI fragment $(\sim 1.9 \mathrm{~kb})$ of pSUP5011 (Simon et al. 1983, 1984) containing oriT, traJ, and traK from plasmid RP4 (Pansegrau et al. 1990) was cloned into the PvuII site of pMIV5 located outside of mini-Mu unit in the region that is nonessential for replication (Fig. 1). After that, the blunted $1.5 \mathrm{~kb} H$ HindIIINdeI fragment of pKD4 (Datsenko and Wanner 2000) containing kan flanked with FRT sites was cloned into 


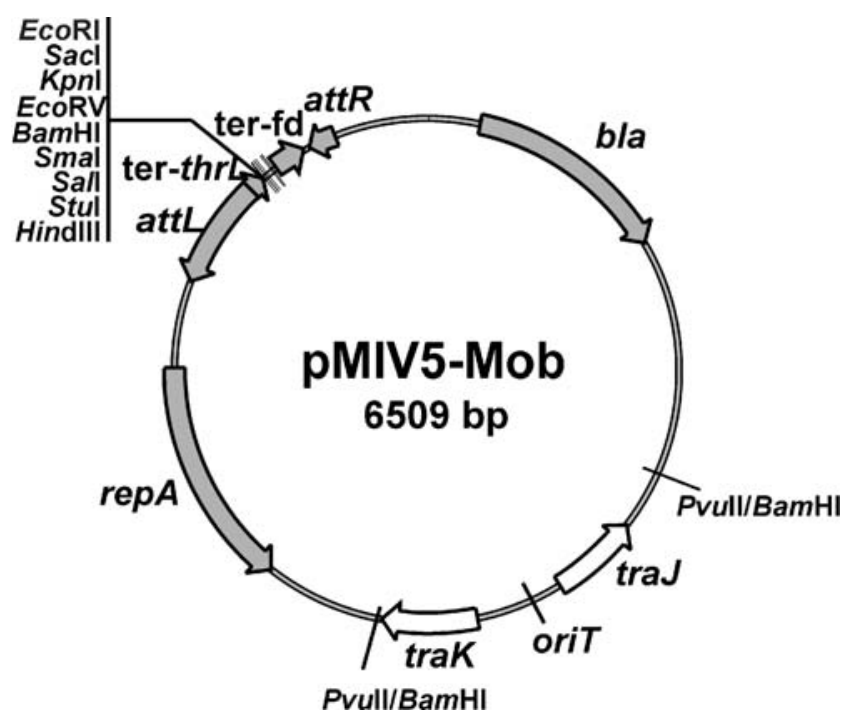

Fig. 1 Map of the vector plasmid pMIV5-Mob. ter-thrL transcription terminator of $E$. coli thrL gene, ter-fd, a tandem transcription terminator of phage fd

EcoRV site of pMIV5-Mob to produce pMIV5-[FRT-Km ${ }^{\mathrm{R}}$ FRT]-Mob (Fig. 2).

Three integrative plasmids were constructed using pMIV5-[FRT-Km ${ }^{\mathrm{R}}$-FRT]-Mob as a vector:

- The blunted 2.9-kb BglII-BamHI fragment of pRT5 (Smirnova et al. 1988) containing the amyE gene for $\alpha$ amylase of $B$. amyloliquiefaciens was inserted into the SmaI site of the vector to obtain pMIV5-[FRT-Km ${ }^{\mathrm{R}}$ FRT]-amy-Mob;

- The EcoRI DNA fragment of pX1918 (Schweizer 1993) containing the structural part of the $x y l E$ gene of the TOL plasmid of P. putida mt-2 (Inouye et al. 1981) was inserted into the EcoRI site of the vector to put the cloned gene under the transcriptional control of $\mathrm{Km}^{\mathrm{R}}$ and create pMIV5-[FRT-Km ${ }^{\mathrm{R}}$-FRT]-xyl-Mob;

- The 1.9-kb EcoRV fragment of pHP17 (Tokmakova, unpublished) containing str $A B$ under control of a weak promoter P17 of M. methylotrophus was inserted into a
SmaI site of the vector DNA to make pMIV5-[FRT$\mathrm{Km}^{\mathrm{R}}$-FRT]-Sm ${ }^{\mathrm{R}}$-Mob (Fig. 2).

The FLP recombinase expressing plasmid pFLP31 was constructed on the basis of pAYCTER3 (Gulevich et al. 2006) derived from pAYC32 (Chistorerdov and Tsygankov 1986) by cloning the BamHI-SmaI fragment $(3.3 \mathrm{~kb})$ of pCP20 DNA (Datsenko and Wanner 2000) containing the gene FLP of $S$. cerevisiae that was transcribed from promoter $\lambda \mathrm{P}_{\mathrm{R}}$ governed by the plasmid encoded $\lambda$ CIts 857 . The pFLP31 can be eliminated from more than $30 \%$ of cells of $M$. methylotrophus after growth for 20 generations at $30^{\circ} \mathrm{C}$ without antibiotic on SEII medium containing $25-30 \mu \mathrm{g} / \mathrm{ml}$ of acridine orange.

Bacterial mating

Integrative and helper plasmids were transferred into strain M. methylotrophus AS1 by biparental mating using E. coli S17-1 bearing the respective plasmid as the donor. The overnight donor and recipient cultures $\left(5 \times 10^{8}-10^{9}\right.$ cell $\left./ \mathrm{ml}\right)$ were mixed at the ratio $1: 10$, harvested by centrifugation, washed with $0.15 \mathrm{M} \mathrm{NaCl}$, and placed on plates with the SEIIa medium containing $10 \%$ of LB broth and $0.5 \%$ of methanol. After $3-4 \mathrm{~h}$ of incubation at $30^{\circ} \mathrm{C}$, the conjugation mixture was washed off from the plates with $1 \mathrm{ml}$ of $0.15 \mathrm{M} \mathrm{NaCl}$ and seeded in a dilution on agar SEIIa medium that contained the appropriate antibiotic (Ap, Tc, or $\mathrm{Sm}$ ) for selection of M. methylotrophus plasmid-carrier variants and $\mathrm{Cm}$ for donor $E$. coli strain counter-selection.

Integration of mini-Mu unit in the chromosome

Transposition of mini-Mu unit into the M. methylotrophus chromosome was performed by conjugative transfer of integrative plasmid to the recipient strain $M$. methylotrophus that contained a helper plasmid. Conjugation was carried out at $37^{\circ} \mathrm{C}$ to induce the synthesis of the transposition factors. The $\mathrm{Km}^{\mathrm{R}}$ integrants were selected
Fig. 2 Linear representation of the integrative plasmids derived from pMIV5-Mob
pMIV5-[FRT-Km $\left.{ }^{R}-F R T\right]-$
Mob (8028 bp)

Mob (8028 bP)

pMIV5-[FRT-Km $\left.{ }^{R}-F R T\right]-$ xyl-Mob (9465 bp)

pMIV5-[FRT-Km ${ }^{R}$-FRT]amy-Mob (10937 bp)

pMIV5-[FRT-Km ${ }^{R}$-FRT]$S m^{R}-$ Mob (9895 bp)
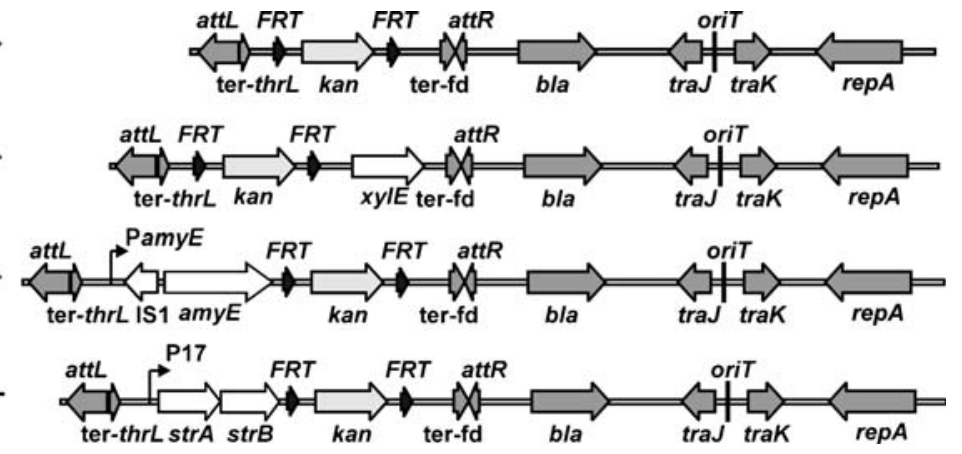
on solid SEIIa medium containing $\mathrm{Km}$ and $\mathrm{Cm}$ for donor counter-selection.

\section{Elimination of [FRT-Km ${ }^{\mathrm{R}}$-FRT] marker}

from the chromosome

pFLP31 was transferred into strain $M$. methylotrophus containing the integrated mini-Mu unit with [FRT-Km ${ }^{\mathrm{R}}$ FRT] marker by mobilization (using plasmid-encoded $\mathrm{Ap}^{\mathrm{R}}$ as the selective marker), and the $\mathrm{Km}^{\mathrm{R}} \mathrm{Ap}^{\mathrm{R}}$ colonies were isolated. The isolated colonies were suspended up to the final concentration of $10^{7} \mathrm{cell} / \mathrm{ml}$ in $5 \mathrm{ml}$ of liquid medium SEIIa with Ap, and the suspension was heated at $42^{\circ} \mathrm{C}$ for $20 \mathrm{~min}$ with the following incubation on a shaker at $37^{\circ} \mathrm{C}$ for $16-18 \mathrm{~h}$ to induce the FLP recombinase synthesis. The culture was then plated on the non-selective SEIIa medium to obtain individual colonies. The latter were analyzed for the occurrence of the $\mathrm{Km}$ and Ap markers on the solid SEIIa medium with the appropriate antibiotic.

Detection of activities of $\alpha$-amylase and $\mathrm{C} 23 \mathrm{O}$

in recombinant $M$. methylotrophus strains

A modified method of insoluble starch (amylopectin azure) hydrolysis was used for the qualitative analysis of $\alpha$ amylase activity (Mantsala and Zalkin 1979). The replicas of the M. methylotrophus::\{[FRT-Km ${ }^{\mathrm{R}}$-FRT]-amy\} integrants were applied to Petri dishes containing the solid SEIIa medium (1.5\% amylopectin azure) and incubated at $37^{\circ} \mathrm{C}$. Visual detection of starch hydrolysis zones that correlated with $\alpha$-amylase-active colonies was performed on the third and fourth day.

The activity of catechol-2,3-dioxygenase (C23O) in the M. methylotrophus:: $\left\{\left[\mathrm{FRT}-\mathrm{Km}^{\mathrm{R}}\right.\right.$-FRT]-xylE\} cells was determined by the appearance of bright yellow color after colonies were sprayed with a solution of catechol (100 mM; Zukowski et al. 1983).

Amplification of mini-Mu unit in the chromosome of $M$. methylotrophus

pTP310 was conjugatively transferred into strain $M$. methylotrophus:: $\left\{\left[\right.\right.$ FRT-Km $\left.\left.{ }^{\mathrm{R}}-\mathrm{FRT}\right]-\mathrm{Sm}^{\mathrm{R}}\right\}$ using $\mathrm{Tc}^{\mathrm{R}}$ as a marker. After overnight incubation at $37^{\circ} \mathrm{C}$ on a shaker cell cultures were plated on the agar SEIIa medium containing different amounts of $\mathrm{Sm}$, and clones resistant to the high concentration of Sm $(2.0 \mathrm{mg} / \mathrm{ml})$ were selected. The helper plasmid was eliminated from the selected clones during aerobic cultivation in the liquid SEIIa medium at $30^{\circ} \mathrm{C}$ for $24 \mathrm{~h}$. The presence of additional copies of mini-Mu unit in the chromosomal DNA of $M$. methylotrophus resistant to high concentration of Sm was confirmed by Southern DNA hybridization.

\section{Results}

Adaptation of the two-plasmid system of Mu-driven transposition to investigations in M. methylotrophus

The helper plasmid pUC-MuAB was constructed and used earlier as a component of the two-plasmid system for $\mathrm{Mu}$ transposition in E. coli (Akhverdyan et al. 2007). A gene for the temperature-sensitive repressor, $c$ ts62, and the genes for transposition factors $\mathrm{MuA}$ and $\mathrm{MuB}$ were located in this plasmid. However, being constructed on the pUC-like replicon, pUC-MuAB could only be replicated and maintained in $E$. coli cells. Therefore, a modification of the helper plasmid was necessary in order to use the system in M. methylotrophus.

Two plasmids were constructed on the basis of broadhost-range replicons of different groups of incompatibility and were capable of being transferred to the methylotrophs by mobilization. One of them, pAET7 $\left(\mathrm{Ap}^{\mathrm{R}}, \mathrm{Sm}^{\mathrm{R}}\right.$, IncQ group; Guerry et al. 1974), was stably maintained in $M$. methylotrophus (percentage of cells that lost the plasmid within 20 generations under non-selective conditions at $30^{\circ} \mathrm{C}$ was no greater than $2 \%$ ). pAET7 could be eliminated with the frequency of no less than $30 \%$ by growing the $M$. methylotrophus in a medium with acridine orange (25$30 \mu \mathrm{g} / \mathrm{ml}$ ) for $24-48 \mathrm{~h}$. The second helper plasmid, pTP310 $\left(\mathrm{Tc}^{\mathrm{R}}\right.$, IncP $\alpha$-group; Ditta et al. 1985; Pansegrau et al. 1994), was maintained in the $M$. methylotrophus only under strictly selective conditions and qualitatively lost from the population when aerobically cultured $\left(30^{\circ} \mathrm{C}, 48 \mathrm{~h}\right)$ in liquid medium without Tc.

The second component of two-plasmid system for $\mathrm{Mu}-$ driven transposition is integrative vector. To increase the efficiency of vector transfer into variety of microorganisms, the fragment containing the RP4-specific mob site was cloned into pMIV5 containing Mu-attL/R sites. Then, $\mathrm{Km}^{\mathrm{R}}$ flanked by the FRT sites was introduced in mini-Mu unit as a marker to give pMIV5-[FRT-Km ${ }^{\mathrm{R}}$-FRT]-Mob (see "Materials and methods"; Figs. 1 and 2).

The obtained pAET7 and pTP310 can be used as helper plasmids, and pMIV5-[FRT-Km ${ }^{\mathrm{R}}$-FRT]-Mob, in turn, as a mobilizable integrative plasmid with a selective marker, in the testing of Mu-driven integration in M. methylotrophus cells.

Mu-driven transposition of $\mathrm{Km}^{\mathrm{R}}$ in the M. methylotrophus chromosome and FLP-mediated curing the marker

The helper and integrative plasmids were applied to transformation of E. coli S17-1 ( Tra $\left.^{+}\right)$, and the obtained strains were used in succession as donors in the conjugation crossings with $M$. methylotrophus AS1. This methylotrophic strain was resistant to $\mathrm{Cm}$, thus permitting the 


\section{a. Simple insertion}

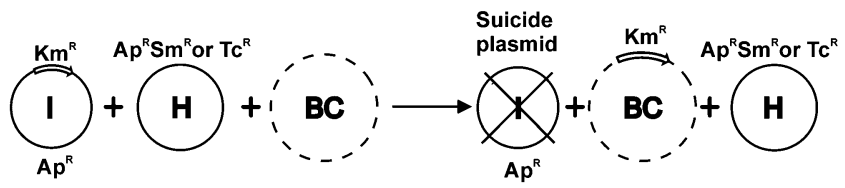

b. Replicative transposition

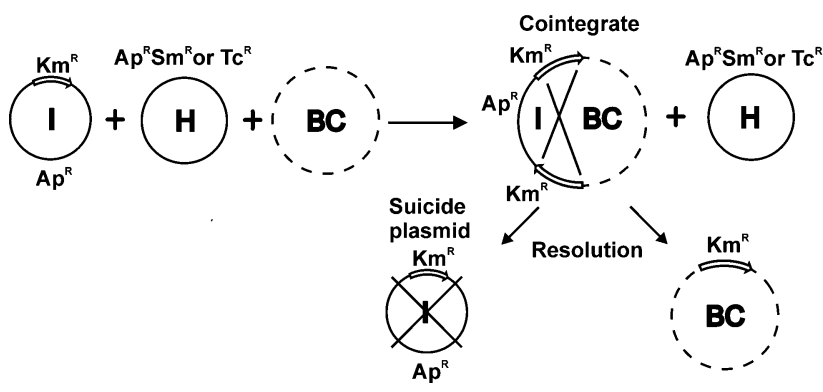

Fig. 3 Simple insertion or replicative transposition of $\mathrm{Km}^{\mathrm{R}}$-mini-Mu unit (an arrow) located in the only replicated in E. coli integrative $\mathrm{Ap}^{\mathrm{R}}$ plasmid $(I)$ in bacterial chromosome $(B C)$ of $M$. methylotrophus in the presence of different helper plasmids $(H)$ carrying $\mathrm{Ap}^{\mathrm{R}}$ and $\mathrm{Sm}^{\mathrm{R}}$ or $\mathrm{Tc}^{\mathrm{R}}$ genes. Transposition of the mini-Mu unit from I can result in a simple insertion in which $\mathrm{BC}$ obtains a copy of this unit (a) or a cointegrate in which I and BC fuse and two copies of the mini-Mu unit border the junction of the fused replicons as direct repeats (b). The cointegrate can subsequently be resolved by a reciprocal recombination event between two mini-Mu units

employment of this antibiotic to the donor counterselection. At the first stage, the helper plasmid pAET7 was introduced in M. methylotrophus (with the efficiency $10^{-2}-10^{-3}$ relative to the initial number of the donor strain cells) by mobilization using $\mathrm{Sm}^{\mathrm{R}}$ marker. At the second stage, M. methylotrophus AS1 that contains a helper plasmid was used as recipient in crossing with $E$. coli S17-1/pMIV5-[FRT-Km ${ }^{\mathrm{R}}$-FRT]-Mob. Mobilization was performed at $37^{\circ} \mathrm{C}$, ensuring the thermo-induced expression of $\mathrm{Mu} A$ and $\mathrm{Mu} B$. The $\mathrm{Km}^{\mathrm{R}}$ integrants were selected with the frequency of $10^{-2}-10^{-3}$ that correlated with the efficiency of plasmid mobilization, i.e., transposition of $\mathrm{Km}^{\mathrm{R}}$ marker occurs practically in each cell of the recipient strain that received the integrative plasmid. Later on, after
pAET7 was cured in the $\mathrm{Km}^{\mathrm{R}}$ cells, the occurrence of mini$\mathrm{Mu}$ unit in the bacterial chromosome was confirmed by genetic analysis $\left(\mathrm{Ap}^{\mathrm{S}}\right.$ ) and PCR (using the mentioned primers P1 and P2 in "Materials and methods," we detected the DNA fragment of about 2,200 bp that corresponded to the size between $\mathrm{Mu}-a t t L / R$ sites in the used $\mathrm{Km}^{\mathrm{R}}$-mini-Mu unit).

Since both integrative and helper plasmids had the same $A p^{R}$ marker, the $\mathrm{Ap}^{\mathrm{R}} \mathrm{Km}^{\mathrm{R}}$ cointegrates that could be formed in the process of replicative transposition would be genetically undistinguishable from the $\mathrm{Km}^{\mathrm{R}}$ integrants obtained due to the simple insertion and containing the $A p^{R}$ helper plasmid (see Fig. 3). During the long procedure required for the pAET7 elimination, the cointegrates could have resolved, giving the same $\mathrm{Km}^{\mathrm{R}}$ phenotype, as the products of simple insertion lost the helper plasmid. Therefore, using pAET7 as the helper plasmid, it was impossible to estimate which of the known mechanisms was involved in the mini-Mu unit transposition into the genome of M. methylotrophus.

An attempt to detect the cointegrates was carried out using another helper, pTP310, that did not contain $\mathrm{Ap}^{\mathrm{R}}$ and carried $\mathrm{Tc}^{\mathrm{R}}$ as a selective marker. After mobilization of pMIV5-[FRT-Km ${ }^{\mathrm{R}}$-FRT]-Mob into M. methylotrophus AS1/pTP310 and selection of $\mathrm{Km}^{\mathrm{R}}$ methylotrophic clones, they were examined for the Ap resistance. Only 30\% of these clones had phenotype $\mathrm{Km}^{\mathrm{R}}$, $\mathrm{Ap}^{\mathrm{S}}$, i.e., they were resulted from either the simple insertion or replicative transposition event, having the cointegrates already resolved. The remaining $70 \%$ of the analyzed clones had the $\mathrm{Km}^{\mathrm{R}}$, Ap ${ }^{\mathrm{R}}$ phenotype being true cointegrates (Fig. 3). Further cultivation of these clones in $\mathrm{Km}$-containing medium (without Ap) led to the selection of $\mathrm{Km}^{\mathrm{R}} \mathrm{Ap}^{\mathrm{S}}$ variants that were the products of cointegrate resolution.

In this work, kan gene flanked with the $F R T$ regions was used as the selective $\mathrm{Km}^{\mathrm{R}}$ marker for mini-Mu unit integration. To excise this marker out of the M. methylotrophus chromosome, the pFLP31 plasmid bearing the FLP recombinase of $S$. cerevisiae under the control of the thermo-inducible promoter $\lambda \mathrm{P}_{\mathrm{R}}$ was constructed. The
Fig. 4 Visual detection of activities of $\alpha$-amylase (starch hydrolysis zones) and $\mathrm{C} 23 \mathrm{O}$ (bright yellow color) in the colonies of M. methylotrophus integrants

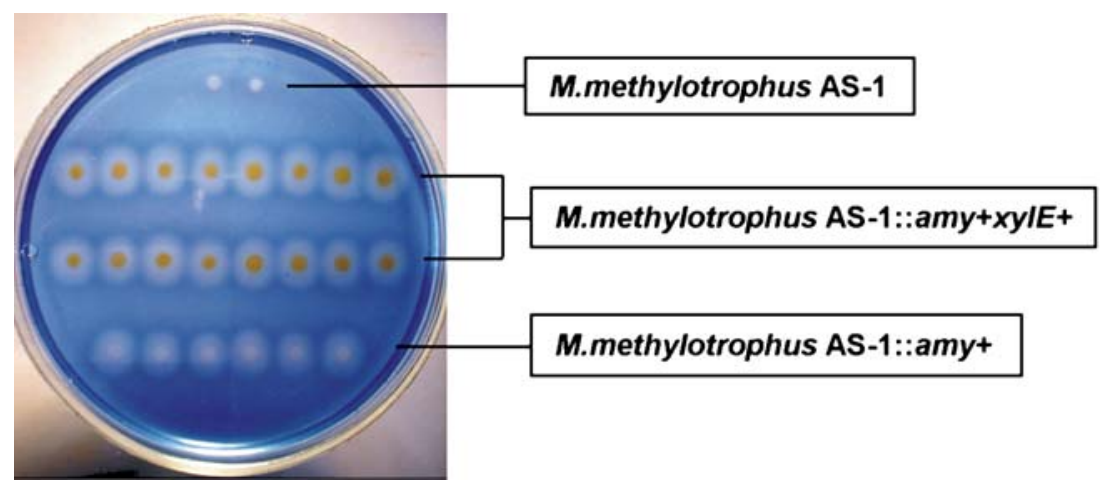




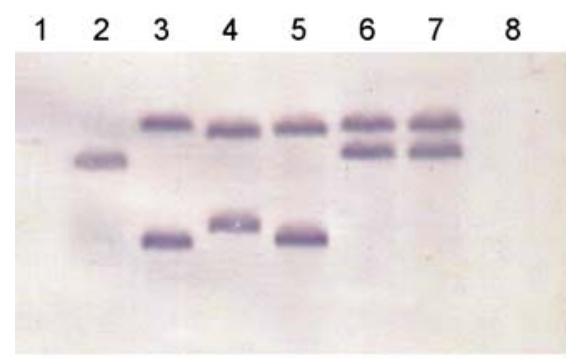

Fig. 5 Southern blot analysis of the clones of M. methylotrophus with integrated and amplified mini-Mu $\left\{\left[\right.\right.$ FRT-Km $\left.\left.{ }^{\mathrm{R}}-\mathrm{FRT}\right]-\mathrm{Sm}^{\mathrm{R}}\right\}$ unit. Genomic DNA, prepared from 15 colonies selected on $2.0 \mathrm{mg} / \mathrm{ml}$ of $\mathrm{Sm}$ and from the control strains was digested with EcoRV, separated by gel electrophoresis in agarose (right) and hybridized with the

pFLP31 was transferred to the strain M. methylotrophus that contained mini-Mu unit with $\mathrm{Km}^{\mathrm{R}}$ marker in the chromosome, and FLP synthesis was thermo-induced. After culture plating, $99 \%$ of the selected $\mathrm{Ap}^{\mathrm{R}}$ clones had the $\mathrm{Km}^{\mathrm{S}}$ phenotype. The $\mathrm{Km}^{\mathrm{R}}$ marker excision was confirmed using PCR (using primers P1 and P2 in PCR we detected the decrease of the amplimers' size from about 2,200 to $815 \mathrm{bp}$ after the marker excision). pFLP31 was eliminated from the obtained $\mathrm{Km}^{\mathrm{S}}$ clones. The resulting markerless strain can be used as recipient for further modifications.

Consecutive Mu-driven transposition of heterologous genes to M. methylotrophus

The multiple modification of $M$. methylotrophus strain was demonstrated using the consecutive integration of a few genes cloned in pMIV5-[FRT-Km ${ }^{\mathrm{R}}$-FRT]-Mob into the $M$. methylotrophus chromosome.

Firstly, the gene for $\alpha$-amylase (amyE) of B. amyloliquefaciens was cloned into pMIV5-[FRT-Km ${ }^{\mathrm{R}}$-FRT]-Mob, and the resulting mini-Mu unit was integrated into the $M$. methylotrophus chromosome using $\mathrm{Km}^{\mathrm{R}}$ as the selective marker. After the FLP-FRT-mediated $\mathrm{Km}^{\mathrm{R}}$ excision was performed, expression of $a m y E$ gene was detected in the obtained strain by zones of hydrolysis on a starchcontaining medium (Fig. 4).

Secondly, a structural part of the $x y l E$ gene in the TOL plasmid of $P$. putida mt-2 was cloned into pMIV5-[FRT$\mathrm{Km}^{\mathrm{R}}$-FRT]-Mob under transcriptional control of the kan promoter. The mini-Mu unit obtained was integrated into M. methylotrophus AS1 and M. methylotrophus AS1:: $a m y+$. The expression of amyE and $x y l E$ in the double integrant strain was demonstrated (Fig. 4).

Mini-Mu unit amplification in the M. methylotrophus chromosome

Integration of mini-Mu unit in the M. methylotrophus chromosome occurs mainly by replicative transposition;

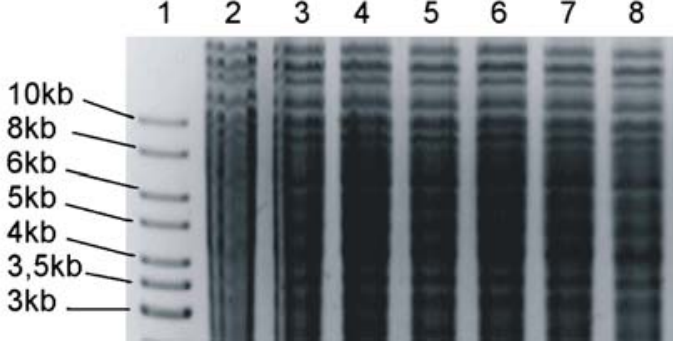

internal fragment of kan used as the probe (left). Five of 15 samples are shown here. Lane 1 DNA ladder, lane 2 a control clone with non amplified mini-Mu unit, lanes 3-7 clones with amplified mini-Mu unit, lane 8 a negative control a wild-type clone

therefore, this mechanism can be employed for the amplification of the integrated genes. Mini-Mu unit $\left\{\left[\right.\right.$ FRT-Km ${ }^{\mathrm{R}}$-FRT]-Sm $\left.{ }^{\mathrm{R}}\right\}$ was used for amplification as a model. It was already known that a single copy of $\operatorname{str} A B$ under the control of P17 promoter can provide the resistance of $M$. methylotrophus to $500 \mu \mathrm{g} / \mathrm{ml}$ of $\mathrm{Sm}$, whereas methylotrophic cells that contained this gene on a moderate-copy-number plasmid were resistant to $>2 \mathrm{mg} / \mathrm{ml}$ of $\mathrm{Sm}$ (Tokmakova, unpublished). In the presence of pTP310 in conditions of induced MuA and MuB synthesis, the clones containing amplified mini-Mu $\left\{\right.$ [FRT- $\mathrm{Km}^{\mathrm{R}}$ FRT]-Sm $\left.{ }^{\mathrm{R}}\right\}$ units were selected on the plates containing $2 \mathrm{mg} / \mathrm{ml}$ of $\mathrm{Sm}$, but with rather low frequency-2 $2 \times 10^{-4}$. The fact that the elevated resistance of the selected clones was due to the mini-Mu unit amplification was proven by the Southern hybridization (Fig. 5). The selected clones had at least two copies of mini-Mu unit in their genomes. Unfortunately, the presence of two mini-Mu units in the chromosome has already provided resistance to such high antibiotic concentrations (up to $10 \mathrm{mg} / \mathrm{ml}$ ) that selection of variants with higher copy number was made impossible. ${ }^{1}$ However, the possibility of mini-Mu unit intrachromosomal amplification in the presence of $\mathrm{Mu}$ transposition factors was demonstrated. It seems probable that this amplification based on the known intrachromosomal replicative transposition resulted in cointegrate formation leading to chromosomal rearrangements due to the inversion of the chromosomal fragment located between two obtained copies of transposon (Metzler 2001). The combined action of replication and site-specific recombination between two copies of transposon is necessary to restore the original position of the first copy during the transposition which

\footnotetext{
${ }^{1}$ The real reason of nonlinear dependence of the level of cell resistance to $\mathrm{Sm}$ on the copy number of mini-Mu unit in $M$. methylotrophus chromosome is unclear. One of the possibilities could be a limitation of antibiotic transport facility, and so at the determined $\mathrm{Sm}^{\mathrm{R}}$ genes expression level, the corresponding protein products could degrade all $\mathrm{Sm}$ penetrated in the cell independently on extracellular Sm concentration.
} 
seems less probable in the absence of the specific counterselection against chromosomal rearrangements. Thus, in our experiments, we were unable to detect clones with the restored positions of the original copy of mini-Mu unit in the chromosome: both chromosomal DNA fragments carried mini-Mu unit and selected by Southern DNA hybridization in new strains differed in size from the corresponding fragment in the strain progenitor (Fig. 5). In case of restored position of the original mini-Mu unit, the new fragment had to be added to the previously detected one at the hybridization's pattern of the new strains. Therefore, all the clones tested in the present study underwent chromosomal rearrangements.

\section{Discussion}

In the present study, the earlier constructed two-plasmid system for Mu-driven integration of recombinant DNA fragments in the E. coli chromosome (Akhverdyan et al. 2007) was adjusted for efficient exploitation in M. methylotrophus. Helper plasmids that are capable of autonomous replication in the methylotrophic cells and carry thermoinducible genes for the Mu transposition factors are the first elements of the modified system. Introduction of these plasmids into $M$. methylotrophus can be performed by electroporation (data not shown) and conjugative transfer. The use of helpers based on replicons of different stability broadens the experimental potential of the system for genetic modification of strains. For example, the helper pAET7 which is stably maintained is suitable to use for multiple consecutive integrations of various mini-Mu units in the same strain or for the several cycles of amplification of an integrated copy of mini-Mu unit by the replicative transposition mechanism. At the same time, the use of the unstable helper, pTP310, is useful for one-cycle integration with rapid selection of a plasmidless recombinant strain.

The second element of the system is the integrative vectors that can be replicated in only $E$. coli strains. These can be introduced into $M$. methylotrophus by conjugative transfer or by electroporation and possess MCS in mini-Mu unit for cloning the genes of interest. The kan gene flanked with the FRT sites provides the selection of the mini-Mu unit integrants and can be excised if necessary from the final strain using pFLP31 plasmid bearing the FLP recombinase gene of $S$. cerevisiae.

The advantage of the system for consecutive integration of a few heterologous genes in the M. methylotrophus chromosome was demonstrated using the $a m y E$ gene from B. amyloliquefaciens and $x y l E$ gene from $P$. putida $\mathrm{mt}-2$ as models. The amplification of the integrated genes in the $M$. methylotrophus genome using the mechanism of replicative transposition was also demonstrated, although the observed efficiency of amplification was significantly lower than that under analogous conditions in E. coli (Akhverdyan et al. 2007). The following modification of the constructed integrative plasmid due to insertion of the small (about $400 \mathrm{bp)}$ DNA fragment carrying phage $\mathrm{Mu}$ enhancer sequence (Yin et al. 2007) in the mini-Mu unit significantly increased efficiency of the possible intrachromosomal amplification: In the same conditions as described in the corresponding part of "Results", we could detect the strains with two to six copies amplified mini-Mu units (Tokmakova et al., in preparation).

An adaptation of the Mu transposition system for use in the M. methylotrophus was based on the previously known functional homology of DNA-bending proteins from various bacteria and E. coli proteins HU and IHF (Swinger and Rice 2004) that are involved in formation of the transpososome structure along with phage-specific DNA elements $(\mathrm{Mu}-a t t L / R)$ and transposition factors $(\mathrm{MuA}$ and MuB; Gueguen et al. 2005). A priori, the simple insertion rather than the replicative transposition mechanism would operate most likely in M. methylotrophus because the former occurs via reparative instead of replicative DNA synthesis, and therefore, lower amounts of host-specific proteins are necessary. However, the predominant formation of cointegrate structures observed in the experiments on primary mini-Mu unit transposition and intrachromosomal mini-Mu unit amplification support the latter statement. In other words, it was experimentally shown that the $M$. methylotrophus proteins, (1) can function in the same way as their analogs in E. coli cells during transpososome formation and (2) ensure all the following stages of the mini-Mu unit replicative transposition. This makes it possible to employ Mu-driven integration and amplification of integrated recombinant DNA to practical applications.

Doubtless, the study of basic aspects of Mu-driven transposition in M. methylotrophus requires further experiments. However, the designed system is already being exploited in the modification of M. methylotrophus strains, and experiments on metabolic engineering (Tokmakova et al. 2007) focused on new biologically active and biotechnologically important substance production.

Open Access This article is distributed under the terms of the Creative Commons Attribution Noncommercial License which permits any noncommercial use, distribution, and reproduction in any medium, provided the original author(s) and source are credited.

\section{References}

Akhverdyan VZ, Savrasova EA, Kaplan AM, Lobanov AO, Vavilova EY, Kozlov YI (2007) Development of the mini-Mu system providing an effective integration and amplification of the genetic 
material in the Escherichia coli chromosome. Biotechnologiya (Russian) 3:3-20

Anthony C (1993) Methanol dehydrogenase in Gram-negative bacteria. In: Davison V (ed) Principles and applications of quinoproteins. Dekker, New York, pp 17-45

Bélanger L, Figueira MM, Bourque D, Morel L, Béland M, Laramée L, Groleau D, Miguez CB (2004) Production of heterologous protein by Methylobacterium extorquens in high cell density fermentation. FEMS Microbiol Lett 231:197-204

Bourque D, Pomerleau Y, Groleau D (1995) High cell density production of poly-beta-hydrobutyrate (PHB) from methanol by Methylbacterium extorquens: production of high-molecular-mass PHB. Appl Microbiol Biotechnol 44:367-376

Chistorerdov AY, Tsygankov YD (1986) Broad host range vectors derived from an RSF1010::Tn1 plasmid. Plasmid 16:161-167

Choi YJ, Bourque D, Morel L, Groleau D, Miguez CB (2006) Multicopy integration and expression of heterologous genes in Methylobacterium extorquens ATCC 55366. Appl Environ Microbiol 72:753-759

Craigie R, Mizuuchi K (1985) Mechanism of transposition of bacteriophage $\mathrm{Mu}$ : structure of a transposition intermediate. Cell 41:867-876

Datsenko KA, Wanner BL (2000) One-step inactivation of chromosomal genes in Escherichia coli K-12 using PCR products. Proc Natl Acad Sci U S A 97:6640-6645

Ditta G, Schmidhauser T, Yakobson E, Lu P, Liang XW, Finlay DR, Guiney D, Helinski DR (1985) Plasmid related to the broad host range vector, pRK290, useful for gene cloning and for monitoring gene expression. Plasmid 13:149-153

Fitzgerald KA, Lidstrom ME (2003) Overexpression of a heterologous protein, haloalkane dehalogenase, in a poly- $\beta$-hydroxybutyratedeficient strain of the facultative methylotroph Methylobacterium extorquens AM1. Biotechnol Bioeng 81:263-268

Groisman EA, Casadaban MJ (1987) Cloning of genes from members of the family Enterobacteriaceae with mini-Mu bacteriophage containing plasmid replicons. J Bacteriol 169:687-693

Gueguen E, Rousseau P, Duval-Valentin G, Chandler M (2005) The transpososome: control of transposition at the level of catalysis. Trends Microbiol 13:543-549

Guerry P, van Embden J, Falkow S (1974) Molecular nature of two nonconjugative plasmids carrying drug resistance genes. J Bacteriol 117:619-630

Gulevich AY, Biryukova IV, Zimenkov DV, Skorokhodova AY, Kivero AD, Belareva AV, Mashko SV (2006) Method for producing an L-amino acid using a bacterium having enhanced expression of the pckA gene. United States Patent 200600 35348

Gunji Y, Yasueda H (2006) Enhancement of L-lysine production in methylotroph Methylophilus methylotrophus by introducing a mutant LysE exporter. J Biotechnol 127:1-13

Gunji Y, Tsujimoto N, Shimaoka M, Ogawa-Miyata Y, Sugimoto S, Yasueda H (2004) Characterization of the S-lysine biosynthetic pathway in an obligate methylotroph, Methylophilus methylotrophus. Biosci Biotechnol Biochem 68:1449-1460

Haapa S, Taira S, Heikkinen E, Savilahti H (1999) An efficient and accurate integration of mini-Mu transposons in vitro: a general methodology for functional genetic analysis and molecular biology applications. Nucleic Acids Res 27:2777-2784

Inouye S, Nakazawa A, Nakazawa T (1981) Molecular cloning of TOL genes $x y l B$ and $x y l E$ in Escherichia coli. J Bacteriol 145: $1137-1143$

Koch B, Jensen LE, Nybroe O (2001) A panel of Tn7-based vectors for insertion of the $g f p$ marker gene or for delivery of cloned DNA into Gram-negative bacteria at a neutral chromosomal site. J Microbiol Methods 45:187-195
Korotkova N, Chistoserdova L, Lidstrom ME (2002) Polybeta-hydroxybutyrate biosynthesis in the facultative methylotroph Methylobacterium extorquens AM1: identification and mutation of gap11, gap20, and phaR. J Bacteriol 184:61746181

Lawes M, Maloy S (1995) MudSacI, a transposon with strong selectable and counterselectable markers: use for rapid mapping of chromosomal mutations in Salmonella typhimurium. J Bacteriol 177:1383-1387

Mantsala P, Zalkin H (1979) Membrane-bound and soluble extracellular $\alpha$-amylase from Bacillus subtilis. J Biol Chem 254:8540-8547

Marx CJ, Lidstrom ME (2001) Development of improved versatile broad host-range vectors for use in methylotrophs and other Gram-negative bacteria. Microbiology 147:2065-2075

Marx CJ, Lidstrom ME (2004) Development of an insertional expression vector system for Methylobacterium extorquens AM1 and generation of null mutants lacking $m t d A$ and/or $f c h$. Microbiology 150:9-19

Metzler DE (2001) Biochemistry: the chemical reactions of living cells: sugars, polysaccharides, and glycopeptides. Academic, New York, USA

Mizuuchi K (1983) In vitro transposition of bacteriophage Mu: a biochemical approach to a novel replication reaction. Cell 35:785-794

Motoyama H, Anazawa H, Katsumata R, Araki K, Teshiba S (1993) Amino acid production from methanol by Methylobacillus glycogens mutants: isolation of L-glutamic acid hyper-producing mutants from $M$. glucogenes strains, and derivation of $\mathrm{L}$ threonine- and L-lysine-producing mutants from them. Biosci Biotechnol Biochem 57:82-87

Motoyama H, Yano H, Terasaki Y, Anazawa H (2001) Overproduction of L-lysine from methanol by Methylobacillus glycogens derivatives carrying a plasmid with a mutated dapA gene. Appl Environ Microbiol 67:3064-3070

Pansegrau W, Balzer D, Kruft V, Lurz R, Lanka E (1990) In vitro assembly of relaxosomes at the transfer origin of plasmid RP4. Proc Natl Acad Sci U S A 87:6555-6559

Pansegrau W, Lanka E, Barth PT, Figurski DH, Guiney DG, Haas D, Helinski DR, Schwab H, Stanisich VA, Thomas CM (1994) Complete nucleotide sequence of Birmingham IncP alpha plasmids. Compilation and comparative analysis. J Mol Biol 239:623-663

Sambrook J, Russell DW (2001) Molecular cloning: laboratory manual, 3rd edn. Cold Spring Harbor Laboratory Press, Cold Spring Harbor, New York

Schweizer HP (1993) Two plasmids, X1918 and Z1918, for easy recovery of the $x y l E$ and $l a c Z$ reporter genes. Gene 134:89-91

Senecoff JF, Bruckner RC, Cox MM (1985) The FLP recombinase of the yeast $2-\mu \mathrm{m}$ plasmid: characterization of its recombination site. Proc Natl Acad Sci U S A 82:7270-7274

Simon R, Priefer U, Puhler A (1983) A broad host range mobilization system for in vivo genetic engineering: transposon mutagenesis in gram negative bacteria. Bio/Technology 1:784-791

Simon R, Priefer U, Puhler A (1984) High frequency mobilization of Gram-negative bacterial replicons by the in vitro constructed Tn5-mob transposon. Mol Gen Genet 196:413-420

Smirnova NA, Sorokin AV, Iomantas YV, Abalakuna EG, Kozlov YI (1988) Mutations in the alpha-amylase gene of Bacillus amyloliquefaciens, leading to a decrease in the temperature of protein inactivation. Mol Biol (Mosk) 22(5):1257-1264

Sokolsky TD, Baker TA (2003) DNA gyrase requirements distinguish the alternate pathways of $\mathrm{Mu}$ transposition. Mol Microbiol 47:397-409

Swinger KK, Rice PA (2004) IHF and HU: flexible architects of bent DNA. Curr Opin Struct Biol 14:28-35 
Tokmakova IL, Abalakina EG, Gorshkova NV, Jomantas YV (2007) Method for inducing L-amino acid auxotrophy to a bacterium belonging to the genus Methylophilus. Patent application RU2007111371 IPC C12N15/63

Tsujimoto N, Gunji Y, Ogawa-Miyata Y, Shimaoka M, Yasueda H (2006) L-Lysine biosynthetic pathway of Methylophilus methylotrophus and construction of an L-lysine producer. J Biotechnol $124: 327-337$
Yin Z, Suzuki A, Lou Z, Jayaram M, Harshey RM (2007) Interactions of phage $\mathrm{Mu}$ enhancer and termini that specify the assembly of a topologically unique interwrapped transpososome. J Mol Biol 372:382-396

Zukowski MM, Gaffney DF, Speck D, Kauffmann M, Findeli A, Wisecup A, Lecocq JP (1983) Chromogenic identification of genetic regulatory signals in Bacillus subtilis based on expression of a cloned Pseudomonas gene. Proc Natl Acad Sci U S A 80:1101-1105 